\title{
FIQH HISAB ARAH KIBLAT : \\ KAJIAN PEMIKIRAN DR. ING KHAFID DALAM SOFTWARE MAWĀQIT
}

\author{
Anisah Budiwati \\ Fakultas Ilmu Agama Islam, Universitas Islam Indonesia, Yogyakarta
}

Email: anisah.budiwati@uii.ac.id

\begin{abstract}
This study analyzes the software determining the direction of Qibla by Dr. Ing. Khafid, geodesy experts in BIG (Goespasial Information Agency) in Mawāqit version 2001.06. The analysis was conducted using qualitative methods. These results indicate that the system of reckoning Qibla direction of Dr. Ing. Khafid is in Mawāqit program version 2001.06. using calculations spherical trigonometry. In addition, see the pattern fiqh qibla direction, he sought to translate the arguments Shar'ie existing in the language of science in line with the opinion of Imam Syafi'i, although there are differences.
\end{abstract}

Keywords: Reckoning direction of qibla, Mawāqit program, and Dr. Ing. Khafid

Penelitian ini menganalisis software penentuan arah kiblat karya Dr. Ing. Khafid, pakar geodesi di BIG (Badan Informasi Goespasial) dalam Mawāqit versi 2001.06. Analisis dilakukan menggunakan metode kualitatif. Hasil penelitian ini menunjukan bahwa sistem hisab arah kiblat Dr. Ing. Khafid yang ada dalam program Mawāqit versi 2001.06. menggunakan perhitungan trigonometri bola (spherical trigonometry). Selain itu, melihat corak fiqh arah kiblatnya, ia berusaha menerjemahkan dalil syar'i yang ada dalam bahasa ilmu pengetahuan senada dengan pendapat Imam Syafi'i, meskipun terdapat memiliki perbedaan/selisih.

Kata kunci : Hisab arah kiblat, program Mawāqit, Dr. Ing. Khafid

\section{PENDAHULUAN}

Kiblat sebagai syarat sah dalam menunaikan ibadah shalat menjadi sebuah persoalan setelah Nabi wafat sampai Islam tersebar di seluruh penjuru dunia (Rusyd, t.th). Hal ini dikarenakan secara geografis, setiap muslim yang berada di luar Mekah tidak dapat menghadap Ka'bah secara tepat seperti orang yang berada di Mekah dan sekitarnya. Di Indonesia, kiblat dalam paradigma masyarakat Indonesia dianggap hanyalah arah barat. Bahkan sampai ketika orang Indonesia yang bertempat tinggal di Suriname akan melaksanakan shalat, mereka melakukan shalat dengan menghadap barat, padahal posisi Suriname posisi titik koordinatnya saja sudah berada di daerah $+04^{0} 00^{\prime}$ LU dan $-55^{\circ} 00^{\prime}$ BB yang seharusnya kiblatnya bukan persis ke barat akan tetapi timur serong ke utara (Muhyiddin, 2004). Menurut penulis, persoalan ini dikarenakan pengetahuan mengenai arah kiblat masih cenderung disederhanakan dan sebagian besar masyarakat kurang mengetahui cara penentuan arah kiblat yang baik dan benar.

Di penghujung tahun 2009 sampai awal tahun berikutnya, arah kiblat menjadi masalah yang diangkat di media massa. Sejumlah media memberitakan pergeseran arah kiblat yang 
disebabkan oleh gempa, telah mengakibatkan pergeseran arah kiblat pada hampir 320.000 dari 800.000 mesjid seluruh Indonesia yang penyebabnya diduga akibat bergesernya lempeng bumi akibat gempa bumi yang melanda tanah air (Republika, 2010). Kemudian adanya diktum fatwa MUI No. 3 tahun 2010 yang menyatakan bahwa kiblat Indonesia hanya arah barat menambah persoalan. Dalam diktum fatwa MUI tersebut disebutkan letak geografis Indonesia yang berada di bagian timur Ka'bah, maka kiblat umat Islam di Indonesia adalah menghadap ke arah barat. Hal ini tentu saja dilatarbelakangi karena adanya persoalan kiblat sebagian besar wilayah Indonesia disebabkan oleh adanya gempa.

Ditambah lagi dengan adanya buku yang ditulis Ali Mustofa Ya'kub (2010) tentang kiblat, bahwasanya kaum muslimin di Indonesia termasuk orang-orang yang berada di sebelah timur Ka'bah, maka kiblat mereka adalah arah barat. Padahal jika kita ketahui secara perhitungan, untuk kiblat di Indonesia sendiri sudah memberikan perbedaan kemelencengan kurang lebih 111,111 1/9 km (Ma'shum, 1992) jika terjadi perbedaan per satu derajat saja.

Dalam usaha meminimalisir persoalan arah kiblat, perkembangan keilmuan hisab rukyah dan teknologi membantu menyelesaikan persoalan kiblat dengan cara perhitungan dan pengukuran. Sebagaimana Susiknan Azhari (2002) menyatakan bahwa bangunan awal pemikiran hisab, termasuk didalamnya hisab arah kiblat di Indonesia sangat dipengaruhi oleh pemikiran Hisab dunia Islam abad pertengahan. Cara penentuan arah kiblat di Indonesia mengalami perkembangan sesuai dengan kualitas dan kapasitas intelektual di kalangan kaum muslimin. Perkembangan penentuan arah kiblat ini dapat dilihat dari perubahan besar yang dilakukan Muhammad Arsyad al-Banjari dan Ahmad Dahlan atau dapat dilihat pula dari alatalat yang dipergunakan untuk mengukurnya, seperti tongkat istiwa' (Gnomon), Rubu' mujayyab, kompas (Huk), sampai pada theodolit dan GPS (Susiknan, 2004). Selain itu sistem perhitungan yang dipergunakan mengalami perkembangan pula, baik mengenai data koordinat maupun mengenai sistem ilmu ukurnya.

Dari banyaknya metode pengukuran yang ada dan didukung dengan kecanggihan teknologi, perhitungan arah kiblat pada masa kini dapat dikemas, dimodifikasi dalam bentuk software-software yang memudahkan pengguna, seperti adanya Qibla direction, Qibla locator, Google earth, dan Google maps. Di antara software program penentuan arah kiblat yang lain yaitu Mawāqit 2001 yang merupakan hasil karya seorang peneliti Bakosurtanal (Badan Koordinasi Survei dan Pemetaan Nasional) Indonesia, yakni Dr. Ing. Khafid.

Ketertarikan penulis pada program kiblat ini adalah ingin mengetahui teori perhitungan yang dipakai dalam Mawāqit 2001 yang pembuatnya memiliki background keilmuan Geodesi. Ia berprofesi sebagai Manager Proyek Pemetaan Dasar Kelautan dan Kedirgantaraan di sebuah Lembaga Pemerintah Non Departemen yang dibentuk untuk melaksanakan tugas pemerintahan tertentu dari Presiden terkait pemetaan dengan inventerisasi sumber-sumber alam, dalam rangka menunjang Pembangunan Nasional yaitu Bakosurtanal (www.bakosurtanal.htm).

Pemilik program Mawāqit yang berpendidikan S1 sampai dengan S3 di Belanda dan Jerman ini banyak menulis tentang penentuan arah kiblat dan ketelitiannya. Ia memberikan penjelasan mengenai penentuan posisi/ koordinat geografis dalam penentuan arah kiblat dengan menggunakan peta analog, peta digital, dari daftar koordinat kota-kota di buku-buku atlas, buku ilmu falak, mengukur dengan GPS, dan lain-lain.

Hal yang menjadi ketertarikan lainnya, di mana pembuat software mawaqit ini menyatakan bahwa perhitungan kiblat dapat didekati dengan konsep geodesi. Penentuan arah kiblat dapat dihitung seperti halnya penentuan arah dalam navigasi. Ia memberi contoh gambaran mengenai arah dari kota Hanoi ke Mekah yang memiliki lintang sama dengan Mekah, ada dua pilihan antara menggunakan Great Circle atau dengan Small Circle. Pendekatan bumi dengan konsep geodesi yaitu ellipsoida memiliki perbedaan sudut dengan perhitungan kiblat yang pada umumnya dipakai. Penjelasan tersebut menjadi referensi bagi penulis untuk 
mengangkat pemikirannya dalam pemikiran hisab rukyah, khususnya hisab arah kiblat, khususnya Mawāqit 2001 ini menggunakan teori geodesi atau tidak.

Berkaitan dengan hal ini penulis melihat bahwa tujuan penelitian yang tidak lain untuk mengetahui software mawaqit dalam kacamata fiqh dan juga dari segi teori keilmuan astronomi ataupun geodesi. Sehingga penelitian ini akan fokus pada upaya mengetahui pemikiran hisab arah kiblat sang pemrogram, corak fiqh hisab arah kiblat yang digunakannya sampai pada sisi keakuratan dari program ini.

\section{REVIEW PENELITIAN SEBELUMNYA}

Secara umum pembahasan arah kiblat terbatas pada segi teknis perhitungan dan perkembangan metode-metodenya. Seperti tulisan yang menguraikan tentang arah kiblat yang secara spesifik membahas bagaimana metode penentuan arah kiblat yaitu Ilmu Falak I (Tentang Penentuan Awal Waktu Shalat dan Penentuan Arah Kiblat di Seluruh Dunia) karya Slamet Hambali (1998).

Selain itu banyak literatur seperti karya Susiknan Azhari (2004) yang berjudul Ilmu Falak Perjumpaan Khazanah Islam dan Sains Modern, yang membahas arah kiblat dalam perspektif syar'i dan sains. Pendekatan historisitas dalam halnya persoalan kiblat lebih mendominasi akan tetapi belum sampai pada pemikiran Dr. Ing. Khafid (Susiknan, 2007). Begitu pula dalam bukunya Abdullah Salam Nawawi (2009), Ilmu Falak, dan Karya Tgk. M.Yusuf Harun (2007) dalam bukunya Pengantar Ilmu Falak, pembahasan arah kiblat yang mengarah pada teknologi alat bantu baru disajikan dalam bentuk penggunaan scientific calculator.

Karya Muhyiddin Khazin dalam bukunya yang berjudul Ilmu Falak dalam Teori dan Praktek, kiblat disajikan dalam materi yang dimulai dengan penggunaan aplikasi arah kiblat pada Rubu Mujayyab, segitiga kiblat, dan busur derajat. Begitu pula buku berjudul Cara Mudah Mengukur Arah Kiblat, di dalamnya berisi tuntunan tentang pengukuran arah kiblat di lapangan yang secara mudah yang dapat diaplikasikan oleh pembaca dan juga berisi tabel arah kiblat dan jaraknya untuk kota-kota di Indonesia (Muhyiddin, 2006).

Ilmu Falak Praktis (Metode Hisab Rukyah Praktis dan Solusi Permasalahannya) karya Izzuddin (2006), mengurai kiblat dari segi fiqh dan aplikasi perhitungan praktis dalam mempelajari ilmu falak di lapangan serta beberapa solusi permasalahan. Buku Pedoman Penentuan Arah Kiblat oleh Departemen Agama RI, Direktorat Jendral Pembinaan Kelembagaan Agama Islam, dan Direktorat Pembinaan Badan Peradilan Agama Islam, menjelaskan tentang hisab arah kiblat dengan ilmu ukur bola (Spherical Trigonometry) dan aplikasi penentuan arah kiblat di lapangan, serta beberapa pembahasan seperti sejarah, kedudukan, dan peranan Badan Peradilan Agama Islam dalam penentuan arah kiblat (Depag, 1995).

Karangan Kh. U. Sadykov, Abu Raihan Al- Biruni dan karyanya dalam Astronomi dan Geografi Matematika, menguraikan tonggak dasar perhitungan penentuan sudut kiblat di permukaan bumi dengan teori trigonometri bolanya. Beberapa karyanya dalam bidang geografi matematika menjulang sampai pada adanya metode baru dalam penentuan ukuran bumi yang belum pernah digunakan oleh siapapun sebelumnya (Sadycov, 2007).

Buku karya Tono Saksono (2007), Mengkompromikan Rukyah dan Hisab, yang meskipun lebih membahas pada sistem penanggalan, kalender Syamsiyah dan Kamariah, dan tinjauan pada pemersatuan hisab dan rukyah, arah kiblat dijelaskan dalam salah satu program Accurate Times, software ini menghitung arah dari jarak terpendek yang menghubungkan lokasi yang diinginkan (pengguna) ke arah Ka'bah di Mekah. Ia juga dapat menghitung waktu kiblat yaitu saat di mana bayangan yang ada di lokasi pengguna menunjukan ke arah kiblat. Selain itu pengguna dapat melihat peta dunia kiblat yaitu peta yang memuat arah-arah kiblat untuk seluruh wilayah dunia dengan warna yang berbeda-beda. 
UNISIA, Vol. XXXVI No. 81 Juli 2014

Ada beberapa makalah yang berkaitan dengan program Mawāqit 2001 seperti makalah tentang Petunjuk Pemakaian Program Mawāqit 2001 versi 2001.06 yang menjelaskan beberapa penggunaan program Mawāqit baik itu mengenai program-programnya yaitu arah kiblat, shalat lima waktu, awal bulan Kamariah, dan beberapa grafik yang memberi informasi mengenai awal bulan Kamariah. Kemudian makalah Hisab dan Rukyah Kontemporer, Peran Kemajuan Teknologi Sebagai Solusi Sekaligus Pemicu Permasalahan Baru yang dalam Seminar Nasional hisab rukyah di IAIN Walisongo (2009) menjelaskan permasalahan hisab dan rukyah kontemporer dalam era kekinian yang bisa menjadi solusi dan pemicu masalah. Akan tetapi kedua makalah ini belum merepresentasikan bagaimana sistem arah kiblat Dr. Ing. Khafid dalam programnya.

Dari telaah pustaka di atas, sejauh penelusuran penulis belum ada pembahasan secara spesifik mengenai pemikiran hisab arah kiblat Dr. Ing. Khafid dalam programnya Mawāqit 2001. Dan kalaupun ada, terbatas hanya pada angel-angel di luar sistem hisab, corak fiqh dan akurasinya.

\section{LANDASAN TEORI}

Adapun landasan teori dalam penelitian itu mencakup teori-teori sebagai berikut :

1. Teori trigonometri bola (spherical trigonometry)

Konsep dasar teori trigonometri ini sebagaimana Ahmad Izzuddin (2010) adalah mengacu pada makna kiblat yaitu "arah menuju Ka'bah di Mekah lewat jalur terdekat melalui lingkaran besar". Di mana azimuth kiblat diperhitungkan dengan mempertimbangkan jarak terdekat dari sebuah lingkaran great circle. Sehingga teori trigonometri bola ini merupakan teori astronomi un sich tanpa mempertimbangkan bentuk bumi sebenarnya. Dalam astronomi, bumi diasumsikan sebuah bola yang memiliki jari-jari yang sama.

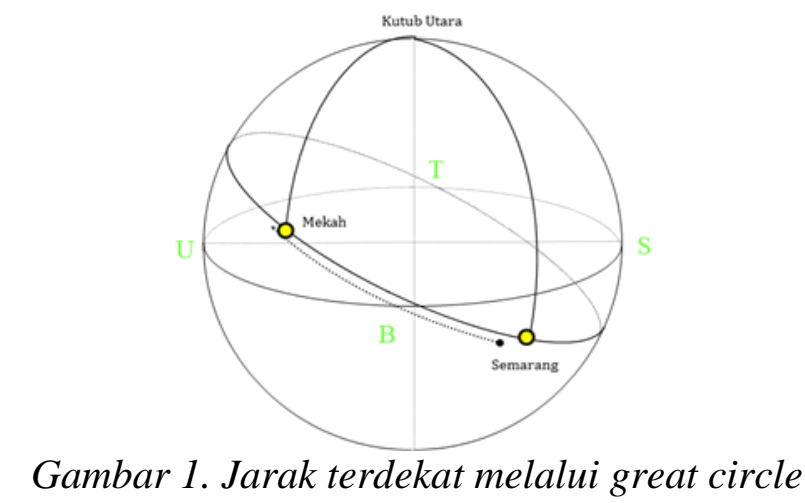

2. Teori geodesi

Sedangkan untuk teori geodesi ini adalah dengan menggunakan bangunan konsep dasar bahwasanya bumi tidak bulat sempurna akan tetapi terdapat benjolan atau lekukan. Elipsoida sebagai pendekatan bumi, yaitu ukuran panjang a bumi lebih dari panjang b. Sehingga bentuknya tidak persis bulat, akan tetapi terdapat penggepengan pada kutubkutubnya (Abidin, 2001) 


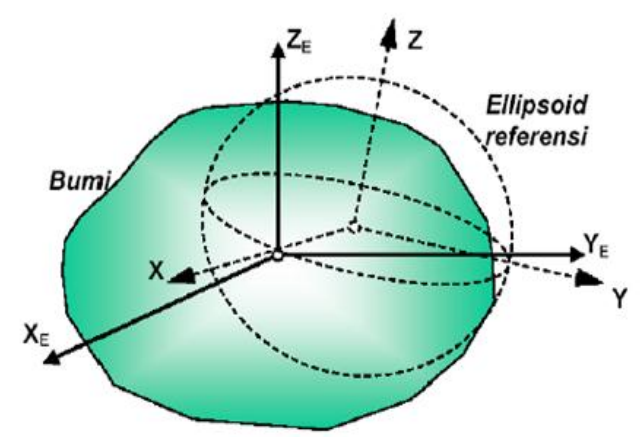

Gambar 2. Asumsi dasar konsep geodesi mengenai bentuk bumi

\section{Ainul ka'bah dan jihatul ka'bah}

Selain dari dua teori tadi, untuk mengetahui kriteria sistem hisab arah kiblat Dr. Ing. Khafid ini dapat dilihat dari kacamata corak fikih yang dipakai. Ada dua pilihan yang merupakan pendapat mayoritas para ulama yaitu Ainul Ka'bah dan jihatul Ka'bah. Ainul $K a$ 'bah ialah istilah bagi orang yang benar-benar melihat Ka'bah secara seperti orang yang ada di Mekah melihat fisik bangunan Ka'bah sendiri. Sedangkan jihatul Ka'bah ialah istilah bagi mereka yang secara geografis tidak dapat melihat Ka'bah secara langsung. Dalam hal ini ada para ulama yang memperkirakan hanya pada arahnya saja dan yang memperkirakan arah yang benar-benar diperhitungkan agar seolah-olah menghadap tepat pada bangunan Ka'bah.

\section{Konsep mengenai data titik koordinat Ka'bah}

Data titik koordinat Ka'bah yang digunakan dapat mempengaruhi hasil perhitungan, sehingga perlu adanya rujukan pada data titik koordinat versi manakah yang digunakan Dr. Ing. Khafid dalam programnya. Sebagaimana Joenil Kahar (2008) yang membagi macam titik koordinat ini menjadi dua yaitu koordinat geografik atau koordinat geosentrik.

\section{METODE PENELITIAN}

Jenis ini adalah jenis penelitian kualitatif yang bersifat deskriptif (descriptive research), yang bertujuan untuk mengetahui karakteristik setiap variabel pada sampel penelitian (Gulo, 2002). Penelitian ini diperlukan untuk menjelaskan bagaimana sistem hisab arah kiblat, corak fiqh dan akurasi perhitungan yang dipakai Dr. Ing. Khafid dalam program Mawāqit.

Sumber data dalam penelitian meliputi sumber primer yaitu program Mawāqit 2001.06 dan hasil wawancara dengan pembuat program yaitu Dr. Ing. Khafid, sehingga diperoleh data yang valid dan lengkap. Kemudian ditambah dengan sumber data sekunder yang diperoleh dari literatur, tulisan, makalah yang terkait Dr. Ing. Khafid, karya-karyanya dan informasi tertulis mengenai program Mawāqitnya serta beberapa buku mengenai program.

Dalam pengumpulan sumber data penelitian ini, penulis menggunakan teknik pengumpulan data dengan cara wawancara dan dokumentasi. Wawancara dilakukan kepada pihak yang terkait langsung yaitu Dr. Ing. Khafid sebagai pengarang. Jenis wawancara baku terbuka yaitu wawancara riwayat secara lisan (Suwandi dan Basrowi, 2008) yang cocok untuk mengetahui tentang konsep pemikiran Dr. Ing. Khafid dalam penentuan arah kiblat. Sedangkan dokumentasi yaitu dengan cara mengumpulkan data dari berbagai tulisan Dr. Ing. Khafid, baik berupa makalah, buku, ataupun tulisan-tulisan untuk diperolehnya informasi lebih lengkap.

Adapun metode yang digunakan untuk menganalisis data-data tersebut adalah metode kualitatif. Hal ini dikarenakan data yang akan dianalisis berupa data yang diperoleh dengan cara pendekatan kualitatif di mana analisis ini pada dasarnya menekankan pada konsep-konsep yang dapat digali pada program (Djam'an, 2009). Dalam menganalisis data, penulis menggunakan metode kualitatif yang bersifat verifikatif yakni dengan cara mengoleksi data, mengumpulkan 
data-data baik dari hasil wawancara dan dokumentasi kemudian melakukan reduksi data dan display data (Suwandi dan Basrowi, 2008). Sehingga didapatkan gambaran data yang sistematis dan dimungkinkan untuk diambil kesimpulan. Tahapan penarikan kesimpulan berkelanjutan sampai pada tahap verifikasi selama penelitian berlangsung. Tahapan-tahapan di atas akan terus berlangsung sampai diperoleh hasil penelitian yang valid. Dalam mengukur tingkat keakuratan Mawāqit, penulis menggunakan teori trigonometri bola dan mengkomparasikan dengan hasil azimuth kiblat satu tempat dari beberapa program. Pada akhirnya akan diketahui bagaimana sistem hisab kiblat Dr. Ing. Khafid dan tingkat keakuratannya dalam program Mawāqit tersebut.

\section{HASIL ANALISIS}

\section{A. Analisis Software Program Mawāqit}

Program Mawāqit ini diawali dari adanya sebuah permasalahan yang berkaitan dengan hisab rukyah yaitu penentuan awal bulan Kamariah. Bersamaan dengan adanya overlap dari penelitian yang sedang dilakukan Dr. Ing. Khafid di Belanda dalam kurun waktu yang tak lama, program perhitungan arah kiblat juga telah melengkapi software ini. Software Mawāqit 1.0 yang merupakan cikal bakal, sebelumnya ditulis dalam bahasa program PASCAL dalam DOS yang kemudian mengalami perkembangan sampai dengan yang terakhir penulis teliti.

Dalam menganalisis sebuah software tidak terlepas pada 3 bagian yaitu masukan (input data), proses dan keluaran (output). Tiga hal tersebut merupakan bagian yang saling berkaitan dan tidak terpisahkan dalam suatu program. Dalam hal ini penulis menganalisis 3 bagian yang penting tersebut yaitu sebagai berikut:

1. Masukan (Input)

Input data dalam program kiblat ini tiada lain mencakup data koordinat Ka'bah dan data koordinat kota/ tempat. Sebuah data dapat dikatakan akurat jika data tersebut tidak menyesatkan, bebas dari kesalahan-kesalahan dan harus jelas mencerminkan maksudnya. Satu hal yang menjadi penilaian dari keakuratan sebuah data yakni kelengkapan (completeness), artinya ketika melihat data koordinat Ka'bah dan koordinat tempat maka apakah data itu benar-benar valid yakni mencakup ketelitian data yang mempertimbangkan penentuan posisi satu titik di permukaan bumi dan seberapa akurat data koordinat tersebut. Berdasarkan penelusuran terhadap program ini, input data terutama lintang dan bujur Ka'bah baru mencapai satuan menit. Sedangkan untuk input data koordinat tempat bisa dirubah oleh users.

2. Proses

Bagian proses ini adalah bagian yang bertugas memproses data yang masuk untuk diolah sedemikian rupa sesuai dengan instruksi programmer. Kegiatan-kegiatan atau proses ini yang mentransformasikan input menjadi bentuk setengah jadi (output). Dalam halnya sebuah proses yang berlangsung dalam aplikasi software maka tentunya hal utama yang menjadi syarat adalah kebenaran (correctness) informasi.

Informasi yang dihasilkan oleh proses pengolahan data haruslah benar sesuai dengan perhitungan-perhitungan yang ada dalam proses tersebut. Artinya jika sebuah informasi menunjukkan sudut azimuth kiblat yang diperlukan oleh seorang user, maka informasi tersebut haruslah sudah benar dan memuat perhitungan-perhitungan matematis yang ada di dalam prosesnya seperti perhitungan selisih bujur Mekah dengan daerah yang dihitung, perhitungan salah satu sudut dalam perhitungan trigonometri bola, dan lain sebagainya.

Proses dalam program arah kiblat Mawāqit ini meliputi perhitungan azimuth kiblat yang digunakan. Proses perhitungan azimuth kiblat dalam program ini menggunakan teori trigonometri bola sebagaimana rumus perhitungan yang ada pada literatur-literatur ilmu falak yang ada. Namun demikian, menurut programmer Mawaqit 
ini, proses perhitungan tidak selamanya mulus, ada beberapa kesalahan dalam penulisan kode sehingga untuk menghitung kota Maroko terjadi kesalahan.

3. Keluaran (output)

Output merupakan hasil kerjasama input data dan proses perhitungan data-data yang ada. Tidak ada yang menjadi syarat utama terkecuali dari adanya input data yang bisa dipercaya dan proses data yang benar. Melihat hasil tampilan program Mawāqit menunjukan informasi atau laporan dokumen berupa petunjuk yang sangat praktis dan mudah difahami oleh users. Berupa tampilan gambar azimuth kiblat pada empat arah mata angin dan angka yang menunjukan azimuth kiblat dalam satuan derajat, serta ditambah dengan informasi jarak antara kota/ tempat yang dihitung dengan Ka'bah.

Dari beberapa penjelasan di atas, penulis melihat bahwa database yang ada dalam program ini merupakan data yang dikumpulkan dari INTERNET dengan beberapa koreksi kebutuhan dan konversi format data. Mawāqit ini pada dasarnya tetap menerima kritikan dan saran untuk kelengkapan datatabese versi berikutnya. Dalam tulisan berjalan pada tampilan Mawāqit ini terdapat beberapa kalimat yaitu:

"sehubungan dengan database yang tersedia dari program ini, baik penulis, lembaga maupun orang lain yang telah terlibat dalam realisasi Mawaaqit ++ ini, membuat jaminan, garansi, tersurat maupun tersirat, tanggung jawab atas kelengkapan, akurasi, atau kegunaannya."

\section{B. Sistem Hisab Arah Kiblat Dr. Ing. Khafid dalam Program Mawāqit 2001}

Untuk mengetahui sistem arah kiblat yang digunakan dalam program ini penulis menganalisis beberapa opsi pilihan perhitungan arah kiblat yang ada dalam program ini. Ada 3 opsi yaitu menentukan arah kiblat dari titik utara, menentukan arah kiblat dari bayang-bayang, dan menentukan arah kiblat dengan memanfaatkan posisi matahari di jalur Ka'bah.

Dari ke tiga opsi tersebut penulis dapat mengambil satu kesimpulan bahwasanya sistem hisab arah kiblat yang digunakan pada program ini menggunakan teori Trigonomeri bola. Hal ini didukung dengan adanya source code program arah kiblat dalam Mawāqit 2001 yang menunjukkan bahwa rumus perhitungan arah kiblat yang digunakan adalah rumus astronomi yakni teori spherical trigonometry. Teori perhitungan azimuth kiblat pada source code yang dipakai yaitu:

$$
\operatorname{cotg} \mathrm{B}=(\sin (\mathrm{a}) . /(\tan (\mathrm{b}) . * \sin (\mathrm{C})))-(\cos (\mathrm{a}) . / \tan (\mathrm{C})) ; \mathrm{B}=\operatorname{atan}(1 . / \operatorname{cotg} \mathrm{B}) ;
$$

Rumus yang ada pada source code ini merupakan rumus perhitungan azimuth pada permukaan sebuah bola. Dengan memperhitungkan 3 titik yaitu titik koordinat Ka'bah, titik koordinat tempat yang dihitung, dan titik utara sejati. Pada hasil sudut azimuth yang ada menunjukkan perhitungan trigonometri bola tanpa memperhitungkan presisi bentuk ellipsoid bumi. Padahal jika menilik dari keilmuannya di bidang geodesi di Pusat Pemetaan Dasar Kelautan dan Kedirgantaraan Bakosurtanal (Badan Koordinasi Survei dan Pemetaan Nasional), sisi keilmuannya tidak muncul dalam program kiblat ini.

Sebagaimana hasil wawancara penulis pula, ternyata pemilik program ini memang memakai teori Trigonometri bola yang menggunakan pendekatan bumi sebagai sebuah bola sebagaimana halnya dalam ilmu astronomi. Ia tidak memakai konsep ellipsoid sebagai pendekatan untuk menghitung arah kiblat pada permukaan bumi. Meskipun pada dasarnya ia mengetahui bahwa Rumus segitiga ini berlaku pada titik-titik di bidang permukaan bola. Sedangkan kenyataannya, koordinat tempat biasanya pada bidang ellipsoid bumi.

\section{Corak Fiqh Sistem Hisab Arah Kiblat Dr. Ing. Khafid dalam Program Mawāqit 2001}

Program Mawāqit sebagai representatif dari adanya sebuah ijtihad dalam menentukan arah kiblat merupakan konsep yang dapat penulis klasifikasikan kepada adanya corak fiqh 
yang ada. Karena melihat dari argumen masing-masing para ulama dengan background yang berbeda dan waktu yang berbeda pula akan menjadi tolak ukur corak fiqh mana yang Dr. Ing. Khafid sepakati, atau menjadi pertanyaan lain, bagaimana konsepnya mengenai arah kiblat.

Merujuk berbagai pendapat para ulama dan memahami konteks dasar-dasar hukum menghadap kiblat yang ada, maka paling tidak dibagi menjadi dua ditinjau dari segi kuat tidaknya prasangka seseorang ketika menghadap kiblat, yaitu menghadap kiblat secara yakin, yaitu menghadap ke Kiblat dengan penuh yakin wajib bagi orang-orang yang berada di dalam Masjidil Haram dan melihat langsung Ka'bah ('Ainul Ka'bah). Kemudian yang ke dua adalah menghadap kiblat dengan Ijtihad, ketika seseorang yang berada jauh dari Ka'bah yaitu berada di luar Masjidil Haram atau di luar Mekah sehingga ia tidak dapat melihat bangunan Ka'bah, maka mereka wajib menghadap paling tidak ke arah Masjidil Haram dengan maksud menghadap ke arah Ka'bah (Jihatul Ka'bah) (Al-Jaziri, t.th)

Kemudian masih dalam Al-Jaziri (t.th) dalam halnya orang yang tidak bisa melihat langsung Ka'bah yaitu Jihatul Ka'bah, penulis melihat bahwa dari pendapat para imam yaitu Imam Syafi'i, Imam Malik, Imam Hanafi, dan Imam Hanbali, pendapat Imam Syafi'i-lah yang berbeda dengan yang lain. Jika yang lainnya hanya mewajibkan menghadap pada arahnya saja, Imam Syafi'i tetap mewajibkan untuk berijtihad dengan petunjuk-petunjuk yang ada .

Kemudian untuk mengetahui corak fiqh hisab arah kiblat Dr. Ing. Khafid dalam program ini, maka dari empat madzhab yang ada yaitu Syafi'iyah, Malikiyah, Hanafiyah, dan Hanbaliyah, konsep fiqh perhitungan dalam program ini termasuk pada pemikiran golongan Syafi'iyah. Karena pada hakikatnya ulama Syafi'i dalam hal menghadap kiblatnya orang yang jauh, wajib menghadap seolah-olah pada bangunan Ka'bah. Artinya ada ijtihad untuk maksimal mengarah pada bangunan Ka'bah. Hal ini telah nampak pada perhitungan yang ada dalam program kiblat ini. Di mana Dr. Ing. Khafid sendiri senada dengan pendapat Imam Syafi'i yang tetap dalam kehati-hatian dalam persoalan menghadap kiblat.

Ia mendefinisikan arah kiblat dalam keilmuan astronomi di mana kiblat itu arah atau jarak terdekat sepanjang lingkaran besar yang melewati kota Mekah (Ka'bah) dengan tempat kota yang bersangkutan. Tidak dibenarkan, misalkan orang-orang Jakarta melaksanakan shalat menghadap ke arah timur seorang ke selatan sekalipun bila diteruskan juga akan sampai ke Mekah, karena arah atau jarak yang paling dekat ke Makah bagi orang-orang Jakarta adalah arah barat serong ke utara. Sehingga tidak hanya menghadap pada arahnya saja, akan tetapi mempertimbangkan jarak terdekat. Meskipun dalam beberapa catatan ia tidak ingin terjebak pada salah satu corak fiqh yang ada. Ia mendefinisikan kiblat dalam bentuk konsep pemikiran yang sesuai dengan keilmuan yang ia miliki. Dari hal ini penulis melihat bahwa dari corak fiqh yang ada, pemilik program Mawāqit 2001 ini memilih pendapat Imam Syafi'i, bahwa dalam persoalan kiblat tetap harus ada usaha maksimal untuk bisa menghadap kiblat dengan tepat.

\section{Akurasi Sistem Hisab Arah Kiblat Dr. Ing. Khafid dalam Program Mawāqit 2001}

Untuk mengetahui keakuratan perhitungan program arah kiblat, maka dapat dilihat dari unsur-unsur yang ada dalam perhitungan ini, baik mengenai input data titik koordinat Ka'bah dan data titik koordinat tempat yang digunakan serta perbandingan dengan data yang ada pada sumber atau program yang lain, yaitu:

1. Titik koordinat Ka'bah

Titik koordinat Ka'bah yang digunakan dalam program ini adalah $21^{\circ} 26^{\prime} \mathrm{LU}$ dan $39^{\circ} 49^{\prime}$ BT. Titik koordinat yang hanya mencakup satuan derajat dan menit, tidak sampai pada satuan detik. Menurut programmer Mawāqit ketika program ini dibuat memang tidak meneliti data koordinat Ka'bah sampai ketelitian detik busur. Ukuran satu derajat 
saja pada waktu itu sudah bagus dan ketelitian data koordinat Ka'bah belum menjadi hal yang fokus.

Hal ini akan berbeda jika dibandingkan dengan beberapa varian data titik koordinat Ka'bah yang lain sebagaimana dalam Susiknan (2004):

\begin{tabular}{|c|c|c|c|}
\hline No & Sumber Data & Lintang & Bujur \\
\hline 1 & Atlas PR Bos 38 & $21^{\circ} 31^{\prime} \mathrm{LU}$ & $39^{\circ} 58^{\prime} \mathrm{BT}$ \\
\hline 2 & Mohammaad Ilyas & $21^{\circ} \mathrm{LU}$ & $40^{\circ} \mathrm{BT}$ \\
\hline 3 & Sa'aduddin Djambek (1) & $21^{\circ} 20^{\prime} \mathrm{LU}$ & $39^{\circ} 50^{\prime} \mathrm{BT}$ \\
\hline 4 & Sa'aduddin Djambek (2) & $21^{\circ} 25^{\prime} \mathrm{LU}$ & $39^{\circ} 50^{\prime} \mathrm{BT}$ \\
\hline 5 & Nabhan Masputra & $21^{\circ} 25^{\prime} 14,7^{\prime \prime} \mathrm{LU}$ & $39^{\circ} 49^{\prime} 40^{\prime \prime} \mathrm{BT}$ \\
\hline 6 & Ma'shum Bin ALI & $21^{\circ} 50^{\prime} \mathrm{LU}$ & $40^{\circ} 13^{\prime} \mathrm{BT}$ \\
\hline 7 & Google Earth (1) & $21^{\circ} 25^{\prime} 23,2 ” \mathrm{LU}$ & $39^{\circ} 49^{\prime} 34^{\prime \prime} \mathrm{BT}$ \\
\hline 8 & Google Earth (2) & $21^{\circ} 25^{\prime} 21,4^{\prime \prime} \mathrm{LU}$ & $39^{\circ} 49^{\prime} 34,05^{\prime \prime} \mathrm{BT}$ \\
\hline 9 & Monzur Ahmed & $21^{\circ} 25^{\prime} 18^{\prime \prime} \mathrm{LU}$ & $39^{\circ} 49^{\prime} 30^{\prime \prime} \mathrm{BT}$ \\
\hline 10 & Ali Alhadad & $21^{\circ} 25^{\prime} 21,4^{\prime \prime} \mathrm{LU}$ & $39^{\circ} 49^{\prime} 38^{\prime \prime} \mathrm{BT}$ \\
\hline 11 & Gerhard Kaufmann & $21^{\circ} 25^{\prime} 21,4^{\prime \prime} \mathrm{LU}$ & $39^{\circ} 49^{\prime} 34^{\prime \prime} \mathrm{BT}$ \\
\hline 12 & S. Kamal Abdali & $21^{\circ} 25^{\prime} 24^{\prime \prime} \mathrm{LU}$ & $39^{\circ} 24^{\prime} 24^{\prime \prime} \mathrm{BT}$ \\
\hline 13 & Moh. Basil At-ta'i & $21^{\circ} 26^{\prime} \mathrm{LU}$ & $39^{\circ} 49^{\prime} \mathrm{BT}$ \\
\hline 14 & Muhammad Odeh & $21^{\circ} 25^{\prime} 22^{\prime \prime} \mathrm{LU}$ & $39^{\circ} 49^{\prime} 31^{\prime \prime} \mathrm{BT}$ \\
\hline 15 & Prof. Hasanuddin & $21^{\circ} 25^{\prime} 21,5^{\prime \prime} \mathrm{LU}$ & $39^{\circ} 49^{\prime} 34,5^{\prime \prime} \mathrm{BT}$ \\
\hline 16 & Ahmad Izzuddin, M.Ag. & $21^{\circ} 25^{\prime} 21,17^{\prime \prime} \mathrm{LU}$ & $39^{\circ} 49^{\prime} 34,56^{\prime \prime} \mathrm{BT}$ \\
\hline
\end{tabular}

Sebagian data lintang dan bujur Ka'bah pada tabel di atas menunjukan adanya data titik koordinat yang memiliki ketelitian sampai pada detik. Tentunya ini sangat berbeda dengan data koordinat yang dipakai oleh Mawāqit yang hanya memakai satuan menit saja. Sehingga akan ada kemungkinan terjadi perbedaan hasil perhitungan sudut disebabkan tingkat akurasi data titik koordinat $\mathrm{Ka}$ 'bah yang dipakai.

Padahal jika melihat beberapa karya tulisnya, ia banyak membahas mengenai ketelitian terutama dalam halnya penentuan posisi. Dengan perkembangan teknologi komputer, cara yang paling mudah yaitu dengan menggunakan peta digital, semisal Microsoft Encarta ataupun Google Earth. Menurut Khafid (2010) cara penentuan posisi yang paling akurat adalah dengan metode GPS (Global Positioning System). Jika dibutuhkan ketelitian 15 meter maka cukup dengan menggunakan GPS handheld, sedangkan untuk ketelitian sampai mm menggunakan GPS Type Geodetic Survey. 
2. Titik koordinat tempat

Titik koordinat tempat dalam Mawāqit ini diambil dari atlas dan dari beberapa software yang semacam di internet. Data koordinat yang ada adalah secara umum untuk mewakili tempat tersebut yang hanya mencapai satuan derajat saja. Keakuratan data koordinat ini tentunya menjadi hal yang berpengaruh pada keakuratan hasil azimuth kiblat. Sehingga tidak menutup kemungkinan pula akan memberikan perbedaan/ selisih azimuth kiblat.

Menurut pemilik program ini, data koordinat tempat yang dihitung memang diambil secara umum dalam satuan derajat karena program ini tidak memperhitungkan seberapa ketelitian, hal yang lebih didahulukan adalah untuk keperluan praktis. Dalam beberapa sumber dapat kita lihat perbedaan lintang dan bujur suatu lokasi yaitu:

\begin{tabular}{lll}
\hline \multirow{2}{*}{ Sumber } & \multicolumn{2}{c}{ Data koordinat kota Semarang } \\
\cline { 2 - 3 } & \multicolumn{1}{c}{ Lintang } & \multicolumn{1}{c}{ Bujur } \\
\hline Mawāqit & $6.58^{\circ} \mathrm{LS}$ & $110.29^{\circ} \mathrm{BT}$ \\
Microsoft Encarta 2006 & $6^{\circ} 58^{`} \mathrm{LS}$ & $110^{\circ} 25^{`} \mathrm{BT}$ \\
Atlas Der Gehele Aarde & $7^{\circ} 00^{`} \mathrm{LS}$ & $110^{\circ} 24^{`} \mathrm{BT}$ \\
Google Earth & $6^{\circ} 58^{`} 17.98^{\prime \prime} \mathrm{LS}$ & $110^{\circ} 25^{`} 30.95^{\prime \prime} \mathrm{BT}$ \\
\hline
\end{tabular}

Data pada tabel di atas sangat jelas menunjukan perbedaan data koordinat suatu tempat dalam beberapa sumber. Hal ini didasarkan pada pengambilan titik koordinat tempat yang dipakai.

Kemudian untuk mengetahui seberapa jauh pengaruh perbedaan titik koordinat Ka'bah dan titik koordinat tempat pada hasil azimuth kiblat (keakuratan sistem hisab kiblat), penulis mengambil contoh kiblat kota Semarang Jawa Tengah ${ }^{1}$. Dengan menggunakan data koordinat Ka'bah yang berbeda akan terlihat perbedaan sudut azimuth yang dihasilkan, yaitu sebagai berikut:

\begin{tabular}{|c|c|c|}
\hline Software program & Koordinat Ka'bah & Azimuth kiblat \\
\hline Mawāqit & $\begin{array}{l}21^{\circ} 26^{\prime} \mathrm{LU} \\
39^{\circ} 49^{\prime} \mathrm{BT}\end{array}$ & $294^{\circ} 31^{\prime} 02^{\prime \prime}$ \\
\hline Google Earth (1) & $\begin{array}{c}21^{\circ} 25^{\prime} 23.2^{\prime \prime} \mathrm{LU} \\
39^{\circ} 49^{\prime} 34^{\prime \prime} \mathrm{BT}\end{array}$ & $294^{\circ} 30^{\prime} 33^{\prime \prime}$ \\
\hline Monzur Ahmed & $\begin{array}{l}21^{\circ} 25^{\prime} 18^{\prime \prime} \mathrm{LU} \\
39^{\circ} 49^{\prime} 30^{\prime \prime} \mathrm{BT}\end{array}$ & $294^{\circ} 30^{\prime} 27^{\prime \prime}$ \\
\hline Ahmad Izzuddin & $\begin{array}{l}21^{\circ} 25^{\prime} 21.17^{\prime \prime} \mathrm{LU} \\
39^{\circ} 49^{\prime} 34.56^{\prime \prime} \mathrm{BT}\end{array}$ & $294^{\circ} 30^{\prime} 31^{\prime \prime}$ \\
\hline
\end{tabular}

${ }^{1}$ Titik koordinat Semarang Jawa Tengah $7^{\circ} 00^{\prime}$ LS dan $110^{\circ} 24^{\prime}$ BT. 
Dari tabel di atas dapat diketahui terdapat perbedaan/ selisih azimuth kiblat kota Semarang 35 detik dengan menggunakan titik koordinat Ka'bah yang berbeda.

Kemudian komponen titik koordinat tempat akan memberikan hasil perhitungan azimut yang berbeda pula. Yaitu ketika data koordinat tempat yang digunakan berbedabeda akan tetapi data koordinat Ka'bah tetap yaitu $21^{\circ} 26^{\prime}$ LU dan $39^{\circ} 49^{\prime}$ BT (Khafid, 2001) yaitu:

\begin{tabular}{ccc}
\hline Software Program & Data koordinat Semarang & Nilai Azimuth kiblat \\
\hline Mawāqit & $\begin{array}{c}6.58^{\circ} \mathrm{LS} \\
110.29^{\circ} \mathrm{BT}\end{array}$ & $294^{\circ} 26^{\prime} 16^{\prime \prime}$ \\
\hline $\begin{array}{c}\text { World Atlas } \\
\text { Microsoft Encarta } \\
2006\end{array}$ & $6^{\circ} 58^{\prime} \mathrm{LS}$ & $294^{\circ} 30^{\prime} 19.15^{\prime \prime}$ \\
\hline $\begin{array}{c}110^{\circ} 25^{\prime} \mathrm{BT} \\
\text { Atlas }\end{array}$ & $7^{\circ} 00^{\prime} \mathrm{LS}$ & \\
\hline & $110^{\circ} 24^{\prime} \mathrm{BT}$ & $294^{\circ} 31^{\prime} 02.88^{\prime \prime}$ \\
\hline Google Earth & $6^{\circ} 58^{\prime} 17.98^{\prime \prime} \mathrm{LS}$ & $294^{\circ} 30^{\prime} 16^{\prime \prime}$ \\
& $110^{\circ} 25^{\prime} 30.95^{\prime}$ BT & \\
\hline
\end{tabular}

Dari tabel di atas dapat diketahui terdapat perbedaan/ selisih 4' 46.88" ketika kita menggunakan titik koordinat Semarang yang bervariasi.

Dari perbandingan tersebut di atas dapat diketahui selisih/ perbedaan program Mawāqit dengan sumber atau program yang lain yaitu antara 35 detik busur sampai dengan 4 menit 46.88 detik (dibulatkan menjadi 5 menit busur).

Untuk mengetahui keakuratan program Mawāqit dibandingkan dengan program yang lain, maka ada satu logika yang bisa dipakai yaitu ketika seseorang yang berada di Semarang $\left(6.58^{\circ}\right.$ LS dan $110.29^{\circ}$ BT) menghadap 1 derajat terlalu ke utara arah kiblatnya $293^{\circ} 25^{\prime}, 42^{\prime \prime}$ atau sebaliknya 1 derajat terlalu ke selatan $\left(21^{\circ} 26^{\prime} \mathrm{LU}\right.$ dan $39^{\circ}$ 49' BT), yakni $295^{\circ} 26^{\prime}$ '42" maka ada satu kesimpulan bahwa penyimpangan 1 derajat dari Semarang $\left(294^{\circ} 26^{\prime} 16^{\prime \prime}\right)$ dapat mencapai jarak 144.730 kilometer.

Begitupula untuk menilai keakuratan dari program kiblat ini yaitu dengan mengetahui jarak selisih dengan sumber atau program yang lain. Berdasarkan perbandingan yang telah dijelaskan sebelumnya ada selisih/ perbedaan sebesar 5 menit busur. Selisih ini dapat dikonversi dalam satuan jarak dengan perhitungan sebagai berikut:

a. Menghitung jarak antara Lokasi dengan Ka'bah

$$
\begin{aligned}
& \mathrm{E}=\mathrm{BT}-\mathrm{BM} \\
& \mathrm{M}=\cos ^{-1}(\sin \mathrm{LT} \times \sin \mathrm{LK}+\cos \mathrm{LT} \times \cos \mathrm{LK} \times \cos \mathrm{E}) \\
& \mathrm{Km}=\mathrm{M} / 360 \times 6,283185307 \times 6378,388
\end{aligned}
$$

Keterangan:

$\mathrm{E}$ $=$ selisih bujur tempat dan bujur Ka'bah

$\mathrm{M} \quad$ = perhitungan sudut 
UNISIA, Vol. XXXVI No. 81 Juli 2014

$$
\begin{array}{ll}
\mathrm{Km} & =\text { perhitungan dalam bentuk jarak }(\mathrm{km}) \\
6,283185307 & =2 \pi \\
6378,388 & =\text { jari-jari bumi }
\end{array}
$$

b. Menghitung Penyimpangan Dari Ka'bah

$$
\mathrm{P}=\mathrm{Km} / \mathrm{SIN}((180-\mathrm{S}) / 2) \times \mathrm{SIN} \mathrm{S}
$$

Keterangan:

$\mathrm{P} \quad=$ penyimpangan dari ka'bah dalam kilometer

$\mathrm{Km}=$ jarak antara ka'bah dengan lokasi dalam kilometer

$\mathrm{S}=$ sudut kesalahan dalam derajat

Dari perhitungan di atas dapat dibuat tabel sebagai berikut:

\begin{tabular}{|l|c|c|}
\hline \multicolumn{1}{|c|}{ MAWĀQIT } & Penyimpangan & Konversi jarak \\
\hline Mekah: & $1^{\circ}$ & $144.752 \mathrm{~km}$ \\
$21^{\circ} 26^{\prime}$ LU dan $39^{\circ} 49^{\prime}$ BT & $1^{\prime}$ & $2.412 \mathrm{~km}$ \\
& $1^{\prime \prime}$ & $0.0402 \mathrm{~km}$ \\
Semarang: & $5^{\prime}$ & $12.062 \mathrm{~km}$ \\
$6.58^{\circ} \mathrm{LS}$ dan $110.29^{\circ} \mathrm{BT}$ & & \\
\hline
\end{tabular}

Sehingga dengan kesalahan 5 menit (35" s/d 4'46.88") mengakibatkan penyimpangan arah kiblat Semarang dari bangunan Ka'bah yaitu 12.062 kilometer.

\section{KESIMPULAN}

Dari analisis yang telah penulis lakukan, ada beberapa kesimpulan yang dapat ditarik, yakni pertama, sistem hisab arah kiblat Dr. Ing. Khafid yang ada dalam program Mawāqit adalah menggunakan teori Spherical Trigonometri. Perhitungan yang digunakan menggunakan konsep astronomi bola yang mengasumsikan bahwa bumi seperti bola. Meskipun pemilik program ini seorang ahli di bidang geodesi, perhitungan arah kiblat pada program ini tetap memakai hitungan astronomi bola tanpa mengkaitkan konsep ellipsoid yang ada pada keilmuan geodesi.

Kedua, corak fiqh arah kiblat Dr. Ing. Khafid dalam program ini condong pada pendapat Imam Syafi'i yang menjadi rujukannya bahwa wajib menghadap Ka'bah, baik bagi orang yang dekat maupun orang yang jauh. Usahanya menerjemahkan makna jihatul Ka'bah terletak pada ilmu astronomi yang memaknai kiblat sebagai jarak terdekat dari satu tempat tertentu melalui permukaan bumi ke Baitullah.

Ketiga, berdasarkan perbandingan dengan sumber input data titik koordinat Ka'bah dan program yang lain, keakuratan hisab arah kiblat dalam program ini memiliki perbedaan/ selisih sekitar 5 menit busur yang dapat diperhitungkan dan dikonversikan dalam satuan jarak yaitu 
sekitar $12.062 \mathrm{~km}$. Sehingga setidak-tidaknya program Mawāqit ini mengarahkan kiblat (atau Mekah).

\section{DAFTAR PUSTAKA}

Abidin, Hasanuddin Z. (2001). Geodesi Satelit. Jakarta: PT. Pradnya Paramita.

Ali, Muhammad Ma'shum. (1992). Durusul Falakiyyah. Jombang: Maktabah Sa'ad bin Nashir Nabhan wa Awladuhu.

Arikunto, Suharsimi. (2006). Prosedur Penelitian Suatu Pendekatan Praktik. Jakarta, Rineka Cipta, edisi revisi IV.

Arsyad, M. Natsir. (1989). Ilmuwan Muslim Sepanjang Sejarah (Cet I). Bandung: Mizan.

Azhari, Susiknan. (2001). Ilmu Falak Teori dan Praktik (Cet.I). Jogyakarta: Lazuardi. .(2004). Ilmu Falak Perjumpaan Khazanah Islam dan Sains Modern, Yogyakarta: Suara Muhammadiyah.

.(2005). Ensiklopedi Hisab Rukyah (Cet. I), Jogyakarta: Pustaka Pelajar. .(2002). Pembaharuan Pemikiran Hisab di Indonesia. Yogyakarta: Pustaka Pelajar.

Basrowi, dan Suwandi. (2008). Memahami Penelitian Kualitatif. Jakarta: Rineka Cipta. Departemen Agama RI. (t.th). Al-Qur'an dan Terjemahannya. Semarang: Toha Putera. Izzuddin, Ahmad. (2006). Ilmu Falak Praktis (Metode Hisab-Rukyah Praktis dan Solusi Permasalahnnya). Semarang: Komala Grafika. .(2007). Fiqh Hisab Rukyah (Menyatukan NU \& Muhammadiyah dalam Penentuan Awal Ramadhan, Idul Fitri, dan Idul Adha). Jakarta: Erlangga.

"Hisab Praktis Arah Kiblat", Makalah pada Diklat Hisab Rukyah Tingkat Dasar Angkatan II Departemen Agama Provinsi Jawa Tengah dan Provinsi D.I Yogyakarta pada tanggal 7-15 Juni $2008 \mathrm{M}$.

. "Melacak Pemikiran Hisab Rukyah Syekh Yasin Al-Padani (Studi atas Kitab Al-Mukhtasor Al-Muhadzab". Laporan Penelitian Fak. Syari'ah IAIN Walisongo, Semarang. 2009.

Gulo, W. (2002). Metodologi Penelitian, Jakarta: PT. Gramedia Widiasarana Indonesia.

Hambali, Slamet. (1998). Ilmu Falak I (Tentang Penentuan Awal Waktu Shalat dan Penentuan Arah Kiblat Di Seluruh Dunia), Semarang, t.p.

Harun, Yusuf. (2008). Pengantar Ilmu Falak. Banda Aceh: Pena.

Kahar, Joenil. (2008). Geodesi. Bandung: ITB.

Khafid. "Pemograman Komputer dalam Hisab dan Rukyah". Makalah pada Kuliah Umum di Surabaya, 11-12 Oktober 2002.

"Petunjuk Penggunaan Program Mawaqit 2001", Makalah Kuliah Umum dan Penutupan Kursus Hisab Rukyah Pengadilan Tinggi Agama Surabaya, 4-5 September 2005.

"Makalah Komputerisasi Program Hisab Rukyat", Makalah Kulian Umum dan Penutupan Kursus Hisab Rukyah Pengadilan Tinggi Agama Surabaya pada tanggal 4-5 September 2005.

"Pelatihan Penentuan Arah Kiblat", Makalah seminar, 15 April 2007.

"Sosialisasi Arah Kiblat di Indonesia”, Makalah seminar Hotel Acacia Jakarta, 15 Maret 2010.

"Ketelitian Penentuan Arah Kiblat", Makalah Seminar Program MUI kota Bogor pada tanggal 4 Agustus 2010.

Khazin, Muhyiddin. (2004). Ilmu Falak dalam Teori dan Praktik (Cet I). Jogyakarta: Buana Pustaka.

. (2005). Kamus Ilmu Falak (Cet. I). Yogjakarta: Pustaka Pelajar.

(2006). Cara Mudah Mengukur Arah Kiblat (Cet. II). Yogyakarta: Buana Pustaka.

King, David A. (1986). Islamic Mathematical Astronomy. London: Variorum Reprints. 
UNISIA, Vol. XXXVI No. 81 Juli 2014

Maskufa. (2009). Ilmu Falaq. Jakarta: GP Press.

MS, Burhani dan Hasbi Lawrens. (t.t). Kamus Ilmiah Populer. Jombang: Lintas Media.

Rusyd, Ibnu al-Qurtuby. (t.th), Bidayatu al-mujtahid wa Nihayatu al-muqtashid, juz. II, Beirut: Darul Kutubil 'Ilmiyyah.

Saksono, Tono. (2007). Mengkompromikan Rukyah dan Hisab. Jakarta: Amythas Publicita \& Center for Islamic Studies.

Salam, Abd. Nawawi. (2009). Ilmu Falak. Surabaya: Aqaba.

Sadycov, Kh.U. (2007). Abu Raihan Al-Biruni dan karyanya dalam Astronomi dan Geografi Matematika (Cet. I). Jakarta: Suara Bebas.

Satoni, Djam'an dan Aan Komariah. (2009). Metodologi Penelitian. Bandung: Alfabeta.

Subana, M. (2005). Dasar-dasar Penelitian Ilmiah (Cet V). Bandung: Pustaka Setia.

Touche, Fred. (1954). Wilderness Navigation Handbook. California: Abacus Graphics.

Ya'kub, Ali Mustafa. (2010). Kiblat Antara Bangunan dan Arah Kakbah. Jakarta: DarusSunnah.

Software Mawaqit 2001 (Islamic Times Keeping Program) versi 2001.06

Word-Atlas, Microsof Encarta, 2006.

Atlas Der Gehele Aarde oleh Bos JF. Niermeyer, JB Wolter-Groningen, Jakarta 1991 yang dikutip dari IslamicFinder.com

\section{Wawancara}

Hasil wawancara dengan Dr. Ing. Khafid : pada April 2009, tanggal 2-3 Agustus 2010, Hasil wawancara via telpon pada Januari 2010, via telpon pada tanggal 25 Desember 2010, dan via email 26 Desember 2010

Hasil wawancara dengan H. Ahmad Izzuddin, M.Ag tentang BHR Rembang

\section{Maktabah Samilah}

Muhammad bin Ahmad Al-Qurtuby, Tafsir Al-Qurtuby (Al-Jami' li ahkam al-quran), Juz. 2

Abdurrahman Al- Jaziri, Fiqh Madzahib al-Arba'ah, Juz 1

Imam Syafi'i, Kitab Al-Umm, juz 6

Imam Syafi'i, Kitab ar-Risalah, juz 1

Kitab Mabsuth, juz 2, t.th

Kitab Syahrul Kabir, juz 1,

Fiqh Hanbali, kitab Al-Mughni, juz 2

al-Qurthuby, Tafsir al-Qurthuby, juz 2

Kitab Shahih Bukhari, Juz 1

\section{Website}

Http://Www.Scribd.Com/Doc/12353927/10-Ilmu-Falak.

Http://beritakbar.blogspot.com/2009/06

Http://www.qiblalocator.com

Http://www.googlearth.com

Http://www.magnetic-declination.com

Http://www.bakosurtanal.htm

http://beritakbar.blogspot.com/2009/06

http://hardiyansyah-ahmad.blogspot.com

Http://www.ilmufalak.or.id/index.php?option=com_content\&view=article\&id=132\&Itemid=13 2

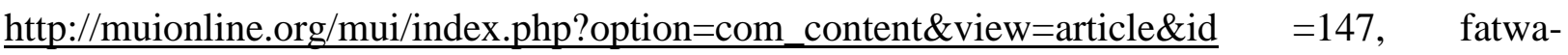
tentang-kiblat 
Fiqh Hisab Arah Kiblat...Anisa B

Http://www.ilmufalak.or.id/index.php?option=com_content\&view=article\&id=132\&Itemid=13 2

Ibnu Zahid Abdo el-Moeid, Menghitung Arah Qiblat dan Menentukannya, : http://moeidzahid.site90.net

\section{Media Masa}

Tabloid Republika, Umat Tidak Perlu Resah, dalam Laporan Utama pada hari Jum'at, 29 Januari 2010

artikel penulis "Kiblat Indonesia sama dengan Barat?” di Radar Semarang pada hari Rabu, 24 Maret 2010. 